\title{
EPIDEMIOLOGY AND EFFECTS OF GASTROINTESTINAL NEMATODE INFECTION ON MILK PRODUCTIONS OF DAIRY EWES
}

\author{
SUAREZ V.H.*, CRISTEL S.L.* \& BUSETTI M.R.*
}

\section{Summary:}

66 Pampinta breed ewes were studied during milking to evaluate the infection and the effect of gastrointestinal nematode on milk production sheep system. Naturally infected ewes on pasture were randomly allocated to two groups: TG, suppressively treated group every four weeks with levamisole and UG, untreated group. Faecal nematode egg counts and larval differentiation were conducted monthly. Successive groups of worm free tracer lambs were grazed with ewes and then slaughtered for worm counts. Test-day milk yield of individual ewes was recorded and ewe machine-milking period length (MPL) were estimated. Faecal egg counts and tracer nematode numbers increased towards midsummer and declined sharply toward the end of the study. TG (188.0 \pm 60 liters) produced more $(p<0.066)$ milk liters than UG (171.9 \pm 52.2$)$ and TG had significantly more extended ( $p<0.041$ ) MPL than those of UG. The present study showed that dairy sheep were negatively affected by worms, even when exposed to short periods of high acute nematode (mainly

Haemonchus contortus) infection.

KEY WORDS : dairy sheep, nematode, milk yield, Pampeana region, Argentina.
Résumé : EFFET DES NÉMATODES PARASITES GASTROINTESTINAUX SUR LA PRODUCTION LAITIEERE DES BREBIS

66 brebis laitières de race Pampinta ont été suivies afin d'évaluer la relation entre infestation par des nématodes gastrointestinaux ef production de lait. Des brebis pâturant sur des prairies naturellement infestées ont été scindées en deux groupes: le premier TG est traité suppressivement toutes les quatre semaines avec du lévamisole, et le second UG, n'est pas traité et sert de témoin. Des examens coproscopiques mensuels ont été réalisés ainsi que des coprocultures pour identifier les espèces de nématodes. Des cohortes successives d'agneaux traceurs lagneaux non infestés et mis sur les parcelles) ont été utilisées afin de déterminer le niveau d'infestation après autopsie parasitaire. Les quantités journalières de lait produit, ainsi que la durée de lactation (MPL) ont été évaluées. Les excrétions d'œufs dans les matières fécales ont augmenté jusqu'au milieu de l'été et ont ensuite déclinés vers la fin de l'étude. Le lot de TG (188 060 litres) a produit plus de lait ( $p<0.066)$ que UG (171.9 \pm 52.2 litres) et MPL était plus long chez le lot TG ( $p<0.041)$. L'étude montre que les brebis sont affectées négativement, même quand elles sont exposées à une infestation importante (principalement Haemonchus contortus) de courte durée.

MOTS CLÉS : brebis laitière, nématode, production laitière, Pampeana region, Argentine.

et al., 2003) and risk factors (Hoste et al., 2006) of GIN in dairy sheep, even though gastrointestinal parasites are a major cause of sheep production losses in the world and Argentina (Armour, 1980; Suarez, 2007), including losses that may amount to $5 \%, 24 \%$ and $25 \%$ for wool, meat and mortality respectively (Suarez et al., 1990) in the Semiarid Pampeana Region. A small number of investigations show the detrimental effects of nematode experimental infections in lactating ewes on both woolled and meat breeds (Leyva et al., 1982; Thomas \& Ali, 1983; Sykes \& Juma, 1984) and on dairy sheep systems of Europe (Fthenakis et al., 2005; Cringoli et al., 2008). Milk production systems in the Pampeana region are different of those of Europe and also predominant sheep GIN species have differences, in view of the fact that Haemonchus contortus is the most dangerous nematode for sheep production (Suarez \& Busetti, 1995). Aspects of GIN epidemiology, effect on production and control should be investigated.

GIN control in the sheep industry in Argentina is based exclusively on the use of anthelmintics, and spe- 
cifically in dairy sheep systems, veterinarians recommend at least two drenches for ewes per year. However, the recent diagnostics of anthelmintic resistance on several dairy farms (Suarez, unpublished data) indicates the need for alternative control strategies based on the knowledge of the local epidemiology of nematode infections in dairy sheep systems.

The aim of the present investigation was to determine the effects of GIN under natural grazing conditions on dairy sheep milk production and to study the nematode infection on adult milk sheep under a grazing system in the Semiarid Pampeana Region of Argentina.

\section{MATERIALS AND METHODS}

\section{LOCATION AND MANAGEMENT}

T The experiment was carried out at the INTA - Anguil Agricultural Experiment Station (La Pampa 2007. province, Argentina) from October 2006 to May

66 Pampinta breed ewes were studied during machine milking from 70 days after lambing until they were dried off during May.

The dairy system comprised a lambing period during August and weaning 45 days after birth. Thereafter, 66 ewes were exclusively machine milked once daily during the morning and grazed on lucerne pasture together with 38 other untreated ewes that were not in the study at a stocking rate of four ewes per ha. At each milking an additional $300 \mathrm{~g}$ of corn was fed per ewe.

\section{EXPERIMENTAL DESIGN}

In late October all the ewes that lambed between $10^{\text {th }}$ August and $10^{\text {th }}$ September, were blocked according to milk production level during the first 34 days of milk recording, age, number of lactations, lamb date and type of birth were randomly allocated to one of two treatment groups. Treated group, TG: ewes $(\mathrm{n}=32)$, were treated every four weeks with levamisole ( $8 \mathrm{mg}$ / $\mathrm{kg}$ subcutaneously) from November $1^{\text {st }}$ and served as a negligible parasitized group and not to evaluate any kind of nematode control; Untreated group, UG: ewes $(n=34)$, were untreated and served as a naturally nematode infected group.

Three ewe levels of production were performed from previous 34 days of milk yield: high producer $(n=20$; mean milk yield of 2,2 liters/day/ewe); medium producer ( $\mathrm{n}=24$; mean yield of $1,43 \mathrm{l}$ /day/ewe); low producer $(\mathrm{n}=22$; mean milk yield of $0.99 \mathrm{l} /$ day/ewe).

Ewe parity number was grouped into three categories corresponding to the sixth or more parities $(n=12)$, to the second up to fifth parities $(n=40)$ and to the first parity $(n=12)$. The number of parities coincides with the age of each ewe.

\section{Parasitological meAsurements}

From October $5^{\text {th }}$ individual faecal nematode egg counts were conducted monthly using the modified McMaster technique (Roberts \& O’Sullivan, 1949). Faecal cultures were similarly done monthly per ewe group for assessing the generic composition of ewe nematode populations according to Suarez (1997).

Tracer lambs: 16 lambs between three and seven months of age, maintained worm free 15 days after having been drenched with levamisole $(8 \mathrm{mg} / \mathrm{kg}$ subcutaneously), were used. From October $10^{\text {th }}$ two lambs were placed on the pasture together with the trial ewes every month for 25 days and were then slaughtered for worm recovery after having been stabled for 12 days under worm free conditions. Necropsy procedures and worm burden estimates were done according to Suarez (1997).

\section{MEASUREMENTS OF ANIMAL PRODUCTION}

From November $1^{\text {st }}$, the health of each ewe was assessed daily at milking and her milk production in liters was recorded using the recording jars in the milking parlor. Likewise, total milk production (TMP) and machine-milking period length (MML) for each ewe were estimated, commencing from the date of the first treatment (November 1st).

Body condition and live weight were also recorded monthly. Eight animals were culled during the trial due to mastitis or pneumonia and their data were not considered for statistical analysis.

\section{STATISTICAL ANALYSIS}

Analysis of variance was conducted with the mixed models procedure of InfoStat Statistical Software (2007). The following fixed effects were included in the models for milk production per ewe as explanatory variables: treatment group (TG and UG), ewe milk production level, ewe parity number and ewe type of birth (triplets, twins or single) and the interactions of treatment group with the factors milk production level, parity number and type of birth. The interval (number of days) between lambing to first drenching date was used as covariable.

Faecal egg counts were $\log (x+1)$ transformed before being analyzed. Differences among least-square means were tested using $\mathrm{F}$ test from ANOVA table. The numbers of ewes of each group, of which the milk production dropped below $200 \mathrm{ml}$ and were thus removed prematurely from the trial, were analyzed by $\mathrm{Chi}^{2}$ analysis. 
RESULTS

\section{PARASITOLOGICAL PARAMETERS}

$\mathrm{F}$ igure 1 shows the ewe worm faecal egg counts over the course of the trial period. Initially, between October and November, the faecal egg counts dropped to low levels, which persisted for a further 80 days. In January, after high rainfalls the mean faecal egg count of UG group increased significantly $(\mathrm{p}<0.0001)$ to a peak of 2104 in February. These egg count levels sharply decline to 314 eggs per $g$ in early March and then the mean egg counts of the UG group

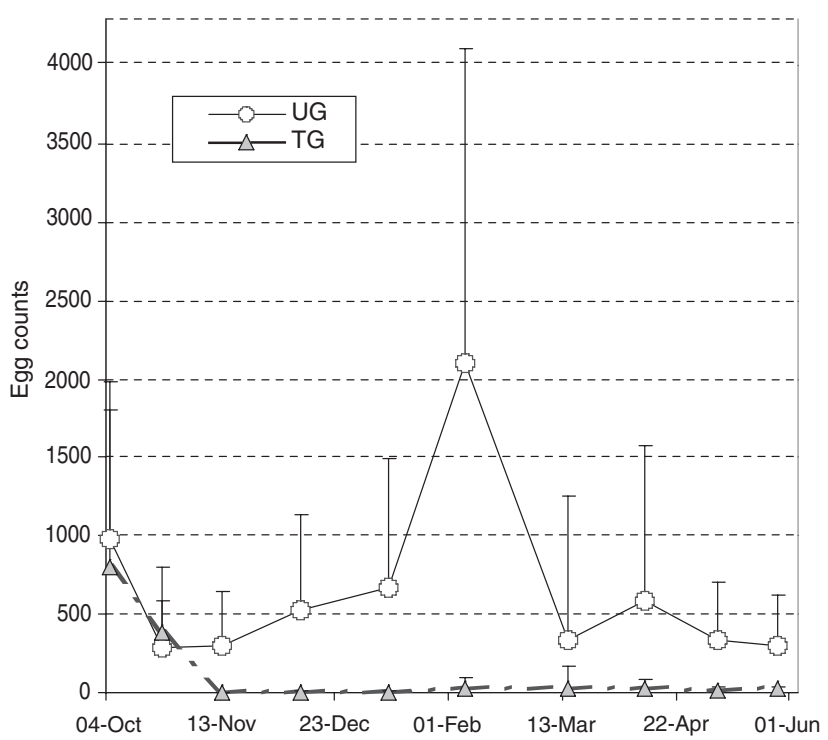

Fig. 1. - Mean faecal egg counts of the milking ewes during the experiment period. UG: untreated group; TG: monthly treated group. remained at low levels until the end of the experiment. Faecal cultures showed that Haemonchus sp. (94.2 to $99.9 \%)$ was the predominant nematode from egg counts.

After their first treatment, the TG group had negligible faecal egg counts throughout the trial.

At the start of the observations, tracer lambs that grazed during October had low worm burdens (Table I), with Nematodirus spp. dominant. The following three tracer pairs (November, December and January) showed a decrease in numbers of Nematodirus spp. and a slow increase of Haemonchus sp. populations. During February and March the highest numbers of nematodes were recovered, mostly Haemonchus contortus. Then during the last two months of the observations, worm burdens, principally $H$. contortus, dropped.

\section{MILK PRODUCTION}

While the mean milk production of the UG group remained at the same level from November to December, that of the TG group showed a small non-significant increase $(\mathrm{p}<0.35)$ after the first treatment (Fig. 2). Thereupon, both groups showed similar patterns during the following two months of the experiment, with nonsignificant differences between treated and untreated groups. In contrast, milk production during February and March was significantly $(\mathrm{p}<0,059)$ larger in the TG than in the UG group (Fig. 2).

Table II summarizes the milk production data. Over the entire trial period the $81 \mathrm{ml}(9.36 \%)$ difference per day per ewe, between the $171.9 \pm 52.2$ liters of TMP of the UG group and the $188.0 \pm 60$ liters of the TG group, approached significance $(p<0.066)$.

\begin{tabular}{|c|c|c|c|c|c|}
\hline Month & Haemon. & Telador. & Trichost. & Nemato. & Total \\
\hline October & $\begin{array}{r}156 \\
10\end{array}$ & $\begin{array}{l}46 \\
30\end{array}$ & $\begin{array}{l}0 \\
0\end{array}$ & $\begin{array}{r}710 \\
2,133\end{array}$ & $\begin{array}{r}910 \\
2,133\end{array}$ \\
\hline November & $\begin{array}{l}110 \\
117\end{array}$ & $\begin{array}{r}110 \\
0\end{array}$ & $\begin{array}{r}10 \\
0\end{array}$ & $\begin{array}{l}610 \\
540\end{array}$ & $\begin{array}{l}840 \\
660\end{array}$ \\
\hline December & $\begin{array}{r}0 \\
278\end{array}$ & $\begin{array}{l}0 \\
0\end{array}$ & $\begin{array}{r}0 \\
12\end{array}$ & $\begin{array}{r}10 \\
454\end{array}$ & $\begin{array}{r}10 \\
744\end{array}$ \\
\hline January & $\begin{array}{l}118 \\
340\end{array}$ & $\begin{array}{r}108 \\
0\end{array}$ & $\begin{array}{l}0 \\
0\end{array}$ & $\begin{array}{l}200 \\
250\end{array}$ & $\begin{array}{l}426 \\
590\end{array}$ \\
\hline February & $\begin{array}{l}8,800 \\
2,500\end{array}$ & $\begin{array}{l}0 \\
0\end{array}$ & $\begin{array}{l}0 \\
0\end{array}$ & $\begin{array}{r}96 \\
0\end{array}$ & $\begin{array}{l}8,896 \\
2,500\end{array}$ \\
\hline March & $\begin{array}{l}8,804 \\
5,474\end{array}$ & $\begin{array}{r}108 \\
0\end{array}$ & $\begin{array}{l}800 \\
328\end{array}$ & $\begin{array}{l}320 \\
466\end{array}$ & $\begin{array}{r}10,032 \\
6,268\end{array}$ \\
\hline April & $\begin{array}{r}898 \\
1,250\end{array}$ & $\begin{array}{r}20 \\
0\end{array}$ & $\begin{array}{l}100 \\
134\end{array}$ & $\begin{array}{l}200 \\
400\end{array}$ & $\begin{array}{l}1,218 \\
1,784\end{array}$ \\
\hline May & $\begin{array}{l}112 \\
110\end{array}$ & $\begin{array}{l}0 \\
0\end{array}$ & $\begin{array}{r}74 \\
120\end{array}$ & $\begin{array}{l}772 \\
700\end{array}$ & $\begin{array}{l}958 \\
930\end{array}$ \\
\hline
\end{tabular}

Haemon: Haemonchus contortus; Telador: Teladorsagia circumcincta; Trichost: Trichostrongylus colubriformis; Nemato: Nematodirus spp.

Table I. - Total number of gastrointestinal nematodes recovered from tracer lambs. 


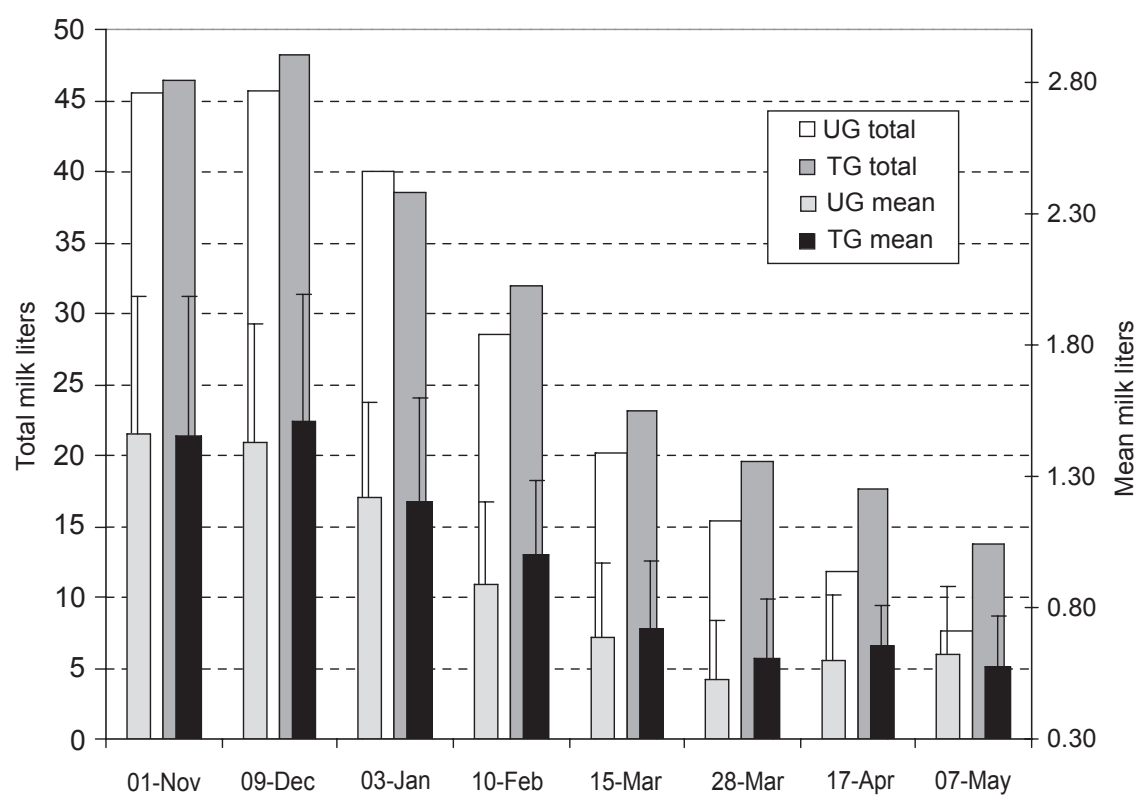

Fig. 2. - Total and mean milk production per group on sampling days. UG: untreated group and TG: monthly treated group.
The machine-milking period length (MML) of the TG group was significantly $(\mathrm{p}<0.041)$ larger than that of the UG group. Table II shows the mean total milk production, mean milk yield differences between January and March and the MML of the ewe groups.

The other explanatory factors that were found to be significant in the linear mixed model of overall milk production parameters were the ewe milk production

\begin{tabular}{lcccc}
\hline Variables & Groups & $\begin{array}{c}\text { Mean } \\
\text { ( } \pm \text { SEM) }\end{array}$ & Minimum & Maximum \\
\hline \multirow{2}{*}{ TPM (liters) } & UG & $171.9 \pm 52.2$ & 85 & 285 \\
& TG & $188.0 \pm 60.1$ & 81 & 339 \\
MYDif & UG & $0.74 \pm 0.40^{\mathrm{a}}$ & -0.16 & 1.70 \\
(l/ewe/day) & TG & $0.60 \pm 0.37^{\mathrm{b}}$ & -0.18 & 1.53 \\
MML (days) & UG & $193.0 \pm 30.7^{\mathrm{a}}$ & 112 & 223 \\
& TG & $204.90 \pm 25.6^{\mathrm{b}}$ & 133 & 223 \\
\hline
\end{tabular}

a, b Within a trait, means with different superscript differ $(\mathrm{p}<0.05)$.

Table II. - Mean $( \pm$ SEM) and ranges of total milk production (TMP), January-March difference in milk yield (MYDif) and machine-milking period length (MML) for levamisole treated (TG) and untreated (UG) groups. level and ewe parity number for MML. There was no significant interaction between the treatments (TG and UG) and any the explanatory factors analysed (ewe milk production level, ewe parity number or type of birth), nor was there any effect of the interval in days between lambing to first drenching date. The productive response to treatment was independent of the mentioned variables. The mean total milk production, mean milk yield differences between January and March and MML for the two treated groups classified by blocks of ewe production level and parity number are shown in Table III.

In May, the number of ewes of the untreated UG group, of which the milk production dropped below 200 to zero $\mathrm{ml}$ and thus had to be withdrawn, was higher (Chi $9.05 ; \mathrm{p}<0.003$ ) than that of the TG. Table IV illustrates the number of ewes of each group that dropped out of the trial from March.

The trial ewes were in good health and body condition and there were no significant differences $(\mathrm{p}<0.88)$ between groups in ewe live weight during the entire study. The initial and end mean live weight of UG

\begin{tabular}{|c|c|c|c|c|c|c|c|}
\hline \multirow[b]{2}{*}{ Variables } & \multirow[b]{2}{*}{ Groups } & \multicolumn{6}{|c|}{ Means $( \pm$ SEM) } \\
\hline & & HY & MY & $\mathbf{L Y}$ & HP & MP & $\mathbf{F P}$ \\
\hline TMP (liter) & $\begin{array}{l}\text { UG } \\
\text { TG }\end{array}$ & $\begin{array}{l}224 \pm 40 \\
239 \pm 56\end{array}$ & $\begin{array}{l}179 \pm 31 \\
196 \pm 30\end{array}$ & $\begin{array}{l}121 \pm 22 \\
125 \pm 30\end{array}$ & $\begin{array}{l}143 \pm 49 \\
148 \pm 47\end{array}$ & $\begin{array}{l}181 \pm 57 \\
197 \pm 67\end{array}$ & $\begin{array}{l}171 \pm 38 \\
197 \pm 39\end{array}$ \\
\hline $\begin{array}{l}\text { MYDif } \\
\text { (l/ewe/day) }\end{array}$ & $\begin{array}{l}\text { UG } \\
\text { TG }\end{array}$ & $\begin{array}{l}1.05 \pm 0.3 \\
0.96 \pm 0.3\end{array}$ & $\begin{array}{l}0.69 \pm 0.4 \\
0.49 \pm 0.3\end{array}$ & $\begin{array}{l}0.53 \pm 0.3 \\
0.36 \pm 0.1\end{array}$ & $\begin{array}{l}0.80 \pm 0.3 \\
0.55 \pm 0.3\end{array}$ & $\begin{array}{l}0.74 \pm 0.4 \\
0.65 \pm 0.4\end{array}$ & $\begin{array}{l}0.70 \pm 0.5 \\
0.49 \pm 0.3\end{array}$ \\
\hline MML (day) & $\begin{array}{l}\text { UG } \\
\text { TG }\end{array}$ & $\begin{array}{l}201 \pm 32 \\
208 \pm 25\end{array}$ & $\begin{array}{l}197 \pm 25 \\
212 \pm 17\end{array}$ & $\begin{array}{l}182 \pm 34 \\
193 \pm 32\end{array}$ & $\begin{array}{l}185 \pm 39 \\
199 \pm 20\end{array}$ & $\begin{array}{l}204 \pm 21 \\
218 \pm 13\end{array}$ & $\begin{array}{l}171 \pm 34 \\
174 \pm 30\end{array}$ \\
\hline
\end{tabular}

Table III. - Mean ( \pm SEM) total milk production (TMP), January-March difference in milk yield (MYDif) and machine-milking period length (MML) for levamisole treated (TG) and untreated (UG) groups, blocked by ewe milk yield level (high yield level: HY; medium yield level: MY; low yield level: LY) and ewe parity (sixth or more parities: HP; second up to fifth parities: MP; first parity: FP). 


\begin{tabular}{ccccc}
\hline Date & Group & $\begin{array}{c}\text { Number } \\
\text { of ewes } \\
\text { remaining }\end{array}$ & $\begin{array}{c}\text { Number } \\
\text { of ewes } \\
\text { removed }\end{array}$ & Chi $^{\mathbf{2}}$ \\
\hline \multirow{2}{*}{ March $15^{\text {th }}$} & UG & 31 & 3 & $1.50 / \mathrm{p}<0.09$ \\
& TG & 32 & 0 & \\
April $17^{\text {th }}$ & UG & 21 & 13 & $4.25 / \mathrm{p}<0.04$ \\
& TG & 27 & 5 & \\
May $7^{\text {th }}$ & UG & 13 & 21 & $9.05 / \mathrm{p}<0.003$ \\
& TG & 24 & 8 & \\
\hline
\end{tabular}

Table IV - - Contingency tables of the number of ewes that remained in milk and ewes that were removed from the trial because their milk production declined below the threshold level for ceased towards the end of the study. UG: untreated group and TG: monthly treated group.

ewes were respectively $86,5 \pm 13,1 \mathrm{~kg}$ and $88,90 \pm$ $15,2 \mathrm{~kg}$ and the corresponding mean live weight for TG ewes were $84,8 \pm 12,5 \mathrm{~kg}$ and $87,5 \pm 14,9 \mathrm{~kg}$.

\section{DISCUSSION}

I n common with previous reports for the region, $H$. contortus was the most prevalent nematode species and Nematodirus spp., Trichostrongylus colubriformis and Teladorsagia circumcincta were less so (Suarez \& Busetti, 1995). Likewise, faecal egg counts of lactating ewes declined initially from October to November, probably after their post-partum faecal egg count peak (Fig. 1), before those of the UG group started rising to a peak early in February. In contrast, the egg counts of TG dropped practically to zero after the first treatment and remained thus until the end of the trial. Suarez (1986) showed that ewes lambing in late winter experienced a post-parturient raise in egg counts during their first two month of lactation, mainly due to $H$. contortus acquired previously, as it seems in the present trial.

The rainfall during the first three months of the trial was only $45 \%$ of the 70 -year average at the Experimental Station. It seems likely that this low rainfall in mid-spring, in addition to the fact that a third of the ewes were treated monthly, were responsible for the small initial worm counts of the tracer lambs until midJanuary. However, under these adverse initial conditions for nematode survival, pasture larval availability reach risk levels when weather conditions become more favorable from February.

Contrary to what would generally be expected, suppressive monthly anthelmintic treatment did not improve milk production in the first part of the trial, during the period of highest production. Unfortunately for the investigation, during this period the larval availability in the pastures was low. Even though a non-significant $(p<0.35)$ response trend after the first treatment
(1 ${ }^{\text {st }}$ November) seemed to be detected, perhaps the performance of some ewes was affected by previous resident worm burdens. But monthly treatments did have an effect in total, since significantly $(\mathrm{P}<0.003)$ more treated than untreated ewes remained in milk until the end of the trial period. This negative effect occurred mainly during a short summer period of three months, at a stage when nematode pasture availability for the ewes was the highest of the study.

The milk production response to treatment suggests that, irrespectively of the genetic production level or number of parities of the ewes, under the design conditions in the trial, treatment mostly improved the milk production by means of the length of the milking period. Fthenakis et al. (2005), also concluded that antiparasitic treatments provided a longer protection of animals against new parasitic infections and contributed to lactation persistence.

In dairy cows many studies with controversial results have been carried out to assess whether anthelmintic treatment have a beneficial effect. The review of Gross et al. (1999) showed that in general there was an economical profit from treatments, with a median increase of $0.63 \mathrm{~kg}$ of milk per cow per day over that of untreated cows.

On the other hand, there are few corresponding references on dairy sheep, as the sheep industry was primarily focused on wool or meat, in which milk production is only considered a maternal aptitude or capacity to rear their lambs. The first available studies with quantitative data were carried out on experimentally infected lactating wool-meat breed ewes and all showed significant effect of nematode infections on production. Sheep infected with 28,000 larvae of $T$. circumcincta showed a $17 \%$ reduction in the milk production (Leyva et al., 1982) compared to worm free controls. Likewise, Thomas \& Ali (1983), who compared the milk yield of ewes orally infected weekly with $2,500 \mathrm{H}$. contortus larvae during pregnancy and lactation, reported a marked weight loss and reduction of $23 \%$ in milk yield. One trial carried out in commercial dairy sheep farms showed a significant (8.9\%) increase in milk yield in ewes treated before and after parturition compared to controls (Juste Jordán \& García Pérez, 1991). Likewise, Cringoli et al. (2008) showed a significant increase in milk production of dairy sheep that ranged from $19 \%$ to $44 \%$ improvement in milk yield after strategic anthelmintic treatments.

Hoste \& Chartier (1993), reported that high producer dairy goats responded better to anthelmintic treatment than the other low producers. Machine-milked goats infected three times at 50 days intervals with 10,000 T. colubriformis and $5,000 \mathrm{H}$. contortus third-stage larvae showed a general reduction in flock milk yield of $2.5-10 \%$ whereas that of the best producers was 13-25\%. Hoste et al. (2006) working with dairy ewes, 
showed higher levels of infections in the primiparous ewes than in the multiparous ewes. In contrast, the present study failed to detect a significant interaction between anthelmintic treatment and the ewe previous milk production level or according to ewe parity number. However, it should be kept in mind that this trial was started 70 days after lambing, at which stage the Pampinta sheep breed are know already to have produce about the $40 \%$ of the total milk production (Suarez, 2004). Therefore at the start of the trial a high proportion of the milk yield would probably have been lost. In addition, by the time the trial commenced, the well-know negative effect of peri-parturient relaxation in resistance (Connan, 1976) will have come to an end already. Despite this fact a significant difference of $9.36 \%$ was recorded in favor of the treated ewes.

Something else to consider is that the two most common dairy breeds in Argentina appear to be more susceptible to nematodes than other wool-meat breeds reared in the same environment. It is probable that such high producers of milk, meat and wool are constantly on a knife-edge as regards a balance between energy required for production and mounting an effective immune response to nematode infections. This is supported by previous results, which indicated that Corriedale lambs developed superior resistance to natural nematode challenge than ${ }^{3 / 4}$ East Friesian $\times{ }^{1 / 4}$ Corriedale lambs (Suarez, 1985).

The present results indicated that even short periods of exposure to a subclinical worm infection consisting mainly of $H$. contortus could have a negative effect on the milk production of dairy sheep. On the other hand, if anthelmintic treatments are increased without consideration to epidemiology and numbers of susceptible nematode larvae in refugia, this may result in selection for anthelmintic resistance (Van Wyk, 2001). These highlight the need for researchers and veterinarians to agree on nematode control strategies, which will help to conserve the efficacy of the available anthelmintic drugs (Coles, 2005).

\section{ACKNOWLEDGEMENTS}

W Te are grateful to Jorge Gavella for his technical laboratory and field assistance and to Luis Miranda for his help in the field. We specially wish to thank Dr Jan Van Wyk for corrections to the manuscript.

\section{REFERENCES}

Armour J. The epidemiology of helminth disease in farm animals. Veterinary Parasitology, 1980, 6, 7-46.

ColEs G.C. Anthelmintic resistance - looking to the future: a
UK perspective. Research in Veterinary Science, 2005, 78, 99-108.

Connan R.M. Effect of lactation on the immune response to gastrointestinal nematodes. Veterinary Record, 1976, 99, 476-477.

Cringoli G.,Veneziano V., Jackson F., Vercruysse J., Greer A.W., Fedele V., Mezzino L. \& Rinaldi L. Effects of strategic anthelmintic treatments on the milk production of dairy sheep naturally infected by gastrointestinal strongyles. Veterinary Parasitology, 2008, 156, 340-345.

Fthenakis G.C., Papadopoulos E. \& Himonas C. Effects of three anthelmintic regimes on milk yield of ewes and growth of lambs. Journal of Veterinary Medicine, Series A, 2005, 52, 78-82.

Gross S.J., Ryan W.G. \& Ploeger H.W. Anthelmintic treatment of dairy cows and its effect on milk production. Veterinary Record, 1999, 144, 581-587.

Hoste H. \& Chartier C. Comparison of the effects on milk production of concurrent infection with Haemonchus contortus and Trichostrongylus colubriformis in high-and low producing dairy goats. American Journal of Veterinary Research, 1993, 54, 1886-1893.

Hoste H., Rulie A.C., Prevot F., Bergeaud J.P., Grisez C., De La Farge F., Jacquiet P. \& Dorchies P. Differences in receptivity to gastrointestinal infections with nematodes in dairy ewes: influence of age and of the level of milk production. Small Ruminant Research, 2006, 63, 150-155.

Juste Jordan R.A. \& Garcia Perez A.L. Effect of treatment with netobimin on milk production of sheep. Veterinary Parasitology, 1991, 38, 173-183.

Leyva V., Henderson A.E \& Sykes A.R. Effect of daily infection with Ostertagia circumcincta larvae on food intake, milk production and wool growth in sheep. Journal of Agricultural Science, Cambridge, 1982, 99, 249-259.

Papadopoulos E., Arsenos G., Sotiraki S., Deligiannis C., Lainas T. \& Zygoyiannis D. The epizootiology of gastrointestinal nematode parasites in Greek dairy breeds of sheep and goats. Small Ruminant Research, 2003, 47, 193-202.

RoBerTs F. \& O'Sullivan P., Methods for egg counts and larval cultures for strongyles infecting the gastrointestinal tract of cattle. Australian Journal of Agricultural Research, 1949, 1, 99-103.

SuArez V.H. Diagnóstico de las parasitosis internas de los rumiantes en la región de invernada. Técnicas e Interpretación. Boletín de Divulgación Técnica (INTA-Anguil), La Pampa, Argentina, 1997, 56, 11-13.

SuAREz V.H. Comparación del efecto de la parasitosis gastrointestinal sobre 2 razas ovinas: ${ }^{3 / 4}$ Ost-Friesian $\times{ }^{1 / 4}$ Corriedale y Corriedale en la región semiárida pampeada. Veterinaria Argentina, 1985, II, 16, 554-561.

SuAREz V.H. Epizootiología de los parásitos gastrointestinales en ovejas en la Región Semiárida Pampeada. Revista de Medicina Veterinaria, Bs. As., 1986, 67, 4, 190-202.

SuAREz V.H. Epidemiología y Control de los Nematodes Gastrointestinales en el oeste de la Región Pampeada, in: Enfermedades parasitarias de los ovinos y otros rumiantes menores en el Cono Sur de América. Suarez V.H., Olaechea F.V., Rossanigo C.E. \& Romero J.R. (eds.), Ediciones INTA, PT. 70, Anguil, Argentina, 2007, 43-62. 
SuARez V.H. Lechería ovina y Raza Pampinta. Revista IDIA, INTA, Argentina, 2004, XXI, 7, 194-200.

Suarez V.H., Larrea S., Busetti M.R., Bedotti D.O., Bulman G.M. \& Ambrustolo R.R. Nematodes gastrointestinales ovinos: su control y efecto sobre los parámetros epizootiológicos, hematológicos y productivos en la región semiárida pampeana (Argentina). Therios, Argentina, 1990, 73, 156-173.

SuAREZ V.H. \& BusetTi M.R. Epidemiology of helminth infections of growing sheep in Argentina's western pampas. International Journal for Parasitology, 1995, 25, 489-494.

Suarez V.H., Busetti M.R., Ortellado Real M.R., Babinec F.J., Garriz C.A., Silva Colomer J. \& Talmon G.D. Características productivas de la raza ovina Pampinta. Therios, Argentina, 1998, 27, 195-203.

SYKes A.R. \& JumA M.H. Effect of chronic experimental infection with Ostertagia circumcincta and anthelmintic therapy on the performance of lactating sheep at pasture. New Zealand Journal of Experimental Agriculture, 1984, 12, 243-249.

Thomas R.J. \& Ali D.A. The effect of Haemonchus contortus infection on the pregnant and lactating ewes. International Journal for Parasitology, 1983, 13, 393-398.

VAN WYK J.A. Refugia-overlooked as perhaps the most potent factor concerning the development of anthelmintic resistance. Onderstepoort Journal of Veterinary Research, 2001, 68, 55-67.

Reçu le 3 novembre 2008 Accepté le 10 février 2009 